\title{
The Poverty Eradication Reflected in Ernest Miller Hemingway's A Farewell to Arms
}

\author{
Irmawati ${ }^{1}$, Burhanuddin Arafah ${ }^{2}$, Herawaty Abbas $^{3}$, Haidir Ali ${ }^{4}$ \\ \{irmawati17f@student.unhas.ac.id ${ }^{1}$, burhan-arafah@unhas.ac.id ${ }^{2}$, herawaty@unhas.ac.id ${ }^{3}$, \\ haidir.haidir93@gmail.com $\left.{ }^{4}\right\}$ \\ Universitas Hasanuddin, Indonesia ${ }^{1,2,3}$ \\ PT Perusahaan Listrik Negara, Indonesia ${ }^{4}$
}

\begin{abstract}
The problem of poverty is one of the big problems in the world. It was reflected in literary works, as a result of cultural products. It is a mistake if see literary works are only a result of the imagination. This research used the descriptive qualitative method to analyze a text in the novel. Then, the researchers analyzed the novel to find out the ideas, thought and solutions from Hemingway as the author of A Farewell to Arms, and also using an additional theory to understand the concepts of poverty. This novel reflected three factors causing poverty. First is the unstable socio-political condition. Second, the in-action of some characters to meet their basic needs cause by depression. Third, the characters lack education that make them do not have the qualified ability to get jobs or set up independent production businesses. It was also revealed that there were four solutions in eradicating poverty by Hemingway reflected in this novel. The first was increasing non-agricultural production consisting of; opening a home stay business in rural areas, making villas in mountainous areas and building hotel business for people who had many capitals in urban areas. The other non-agricultural productions were to become a sculpture carver, and to open a clinic for expert doctors. The second is an increase agricultural business with quality methods. The third way is through education to improve skills in various fields of production. The last was helping basic needs to the poor.
\end{abstract}

Keywords: Eradicating Poverty, Expressive Approach, Author, Reflected

\section{Introduction}

Some people often assume that literary works are only a result of the imagination. It is purely fantastic work that is useful as entertainment only, and it talks about itself. Even though in fact the literary works are the cultural products that have social benefits because the works by the author reflects what has existed in the community, both the problems and solution offered by the writer through the works at that time. This is related to the duties of the poet which is mentioned of Horace in Fairclough [1] that the effect of poetry produced is combining the dulce (useful) and utile (give a favor). It means that literary works contain two functions; these are to entertain and benefits to the lives especially for solving readers' problems through literary works. Literature research is scientific research that has the basis of science because the literary research is analyzed systematically and procedurally.

Literature is regarded to the text such as; plays, novels, short stories, poetry, essays and others. The author tries to reflect his or her experiences, ideas, solutions and critics in his work. So, the reader is able to gain advantage reflected by the author in the series event in the novel. 
A Farewell to Arms novel shows the typical way of Hemingway's written how he describes the event briefly but very clearly with beautiful simple metaphor.

One of the big problems which have always happened is the problem of poverty. The researcher collected data on BPS site in Indonesia over the past four years. The poverty in Indonesia report shows that in (Official Statistics, Poverty Profile in Indonesia September 2017 No. 05/1/Th. XXI, 2 January 2018) on September 2017, the number of poor people (population with per capita expenditure per month under Poverty Line) in Indonesia reached 26.58 million people (10.12 percent), a decrease of 1.19 million people compared to the conditions on March 2017 which amounted to 27.77 million people (10.64 percent). The percentage of poor people in urban areas $2017 / 3$ was 7.72 percent, down to 7.26 percent 2017/9. While the percentage of poor people in rural areas in March 2017 was 13.93 percent, down to 13.47 percent in September 2017. However, the number of poverties decreases in 2018 but the fact that the number of poor people in Indonesia fluctuates. Seeing this phenomenon, the researcher believes that the Indonesia government has made serious efforts to give the best solutions. However, there is not wrong if the researcher as a literary student also tries to provide the solutions from a literary perspective on eradicating poverty [2].

\section{Methodology}

\subsection{Method of Collecting Data}

Method is the way to applied theory; Technique is how to do the methods. The researchers were collected data based on this type of research: qualitative research. The steps taken by the researchers are as follows:

a. The researchers used the close reading method to read A Farewell to Arms and then they were searching and looking at the relationship between the intrinsic elements in the novel. The next step, the researchers given a sign through sticky notes on dialogue, narration, monologue related to the research theme in the novel.

b. The researchers conducted a comprehensive reading of literary theories especially the theories that are relevant to this research such as; studying the Abrams theory in the book The Mirror and The Lamp, and other supporting theories for instance pure theories about poverty.

c. In addition, the researchers used many types of dictionaries to find difficult word meanings in the novel and supporting data used as a reference.

\subsection{Method of Analyzing Data}

Data analysis in this study uses descriptive qualitative method. This research emphasizes the very deep explanation of the phenomenon through data collection in the novel that is very carefully. The analytic process that the researchers performed are:

a. The researchers conducted a close-reading process to identify some data from narrations, dialogues or internal monologues from the novel A Farewell to Arms. These data will be analyzed by intrinsic elements that unite together to show the meaning.

b. The writers do coding process in the main data. At this stage, the researcher begins to mark using color pens on issues related to the causes of poverty in the novel. Then they continued to mark issues that are solutions to poverty problems written by the author in the novel $A$ Farewell to Arms using other colored pens. The last stage of the coding process is that the 
researchers wrote all the issues along with the pages of the issues related to the research in one book/file to facilitate data management.

c. The researchers continue to discover data using the Abrams's expressive approach. This approach is used to dissect the work through helping the pure poverty eradication theory without separated by structural described earlier. Then the writers looked for data on poverty problems and the solutions written by the author in the novel A Farewell to Arms.

\subsection{Source of Data}

The sources of data in this research are divided into two categories which are presented as follows:

a. Primary data

The main data are observed from reading novel A Farewell to Arms by Hemingway itself. The data was gotten from a part of plot events related to the aspect of the poverty eradication occurred in the novel. They are shown through dialogues of characters, monologue and author's narrations.

b. Supporting Data

Supporting data are the data taken from external sources outside the novel. The data are provided additional information to support the primary data to prove the application of theory. The external sources consist of previous books, journals, online article, and essays.

\subsection{Tools of Data Collection}

The researchers use several tools in the study as follows:

a. Brightly colored marker (highlighter); used to mark important data (blue: to mark data that causes poverty. Green: to mark the author's solution to poverty reduction. Red: used for the main idea of each sentence).

b. Sticky note: the researchers use to give a sign on the page that related to point 1 that put on the edge of the novel paper.

c. Pen and pencil color full; to researcher's main ideas, supporting ideas and pages in a small book.

d. 15-inch laptop: for typing, processing and storing research data.

\subsection{Research Procedure}

This research arranges procedure to make it constructed systematically based on the principles of science. They were presented as below:

a. The researchers read the novel carefully as the main sources by close reading, identify the intrinsic elements before starting to some problems contain in novel.

b. The researchers identify the scope of problems to be analyzed. The researcher started to highlight the important issues which are relevant to research problems using brightly colored markers, so the researcher can classify and limit the problems of the research;

c. The researchers conducted data collection which related to this research. Finding previous study from the novel and marking the gaps among them. Then they read, gain and collect all data and information that have relevance to the subject from the other references such us the books, journals and articles accord with the research.

d. Study the concept of poverty that divided into; understanding poverty concept, factors cause poverty and how to eradicate this problem. Then the researcher analyzes the data using 
expressive approach by Abrams to answer the researcher problems without forgotten the biography of Hemingway as the author of this novel.

e. The last step is the researchers draw the conclusion based on the analysis that related to the research problems of the poverty eradication in Ernest Miller Hemingway's A Farewell to Arms. The conclusion was given an overview of all the elements in this study.

\section{Finding and Discussion}

\subsection{Finding}

\subsubsection{The Concept of Meyer H. Abrams Theory}

More than 2000 years ago in the 14th century BC, Horace had described the function and duties of a poet namely "Dulce and Utile". This means that the beginning of the literary works has function for providing enjoyment and benefit to others. This is highlighted in Classical Literary Criticism translated by T.S. Dorsch "Poets aim at giving either profit or delight, or at combining the giving of pleasure with some useful precepts for life" [3].

The approach of literary works should look at all aspects in works, such as; the literary work itself, the author, the universe as a reflection of the work and it cannot be separated from the literary works benefits for the reader. According to Abrams [2], there are four elements in all situation of an art or a literature works which called "A Triangle Theory".

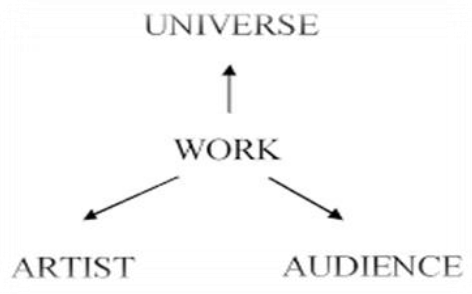

There is the works, the artistic product itself, it is human product, an artifact, the second is common element is the artist who is creator or writer the literary works which called expressive approach. Third is audience who are read the works is taken to have a subject which directly or deviously, is derived from existing things- to be a boat, or signify, or reflect something which either is, or some relation to as an object state affair. These third elements consist of people, (action, ideas and feeling, material thing and events, or super-sensible essences) which have frequently been denoted by word of all work, nature. In the last element, the art/literary works have addressed, or to whose attention, at any rate, it becomes available. He made four explanations between universe, work, artist and audience; those are [4].

a. An approach that emphasizes the work itself; objective approach.

b. An approach that emphasizes the author; expressive approach.

c. An approach that emphasizes the universe; mimetic approach.

d. Approach that focuses on readers; pragmatic approach. 


\subsubsection{Definition and Orientation of The Expressive Approach}

The researchers think that the authors of literary works need a special place. The authoresses' creativity not only comes from their imagination, but they make various steps and efforts before writing. The authors see social phenomena, make observations and very deep contemplation towards these phenomena, then reflects them in their writing of literary works.

Longinus argued that literary works are grandeur, excellence, have the qualities and nobility of a poet that give the lessons for connoisseurs and readers literary works. Longnius stated in Dorsch that there are five sources of truth from poets, at that time there were no short stories and novels, benefits to literary readers, namely: The first and most important is the ability to form grand conceptions. The second comes the stimulus of powerful and inspired emotion. The sublime has two elements of the sublime are very largely innate, while the remainder are the product of art - that is, the proper formation of the two types of figures, figures of thought and figures of speech, together with the creation of a noble diction, which in its turn may be resolved into the choice of words, the use of imagery, and the elaboration of the style. The fifth source of grandeur is the total effect resulting from dignity and elevation [5].

The orientation of expressive theory is approach which believes that the literary work comes or written by expressing the author's ideas, the style of language used, the values included in his poetry and his deep feelings expressed through writing activity with the help of the special language of each writer that we call style in using figurative language. By using the expressive theory, the reader can know the powerful feeling or emotion, proper subject, language effect, author opinion and the values of the author which is reflection in works. Then the reader also can know the author's era life, for instance Wordsworth in romantic period by his poetry "Lyrics of Ballad". Abrams explains the process of literary works in this case is poetry, as below:

"...that the poetry is the overflow, utterance, or projection of the thought and feeling of the poet; or else (in the chief variant formulation) poetry is defined in terms of the imaginative process which modifies and synthesizes the image, thoughts, and feeling of the poet. This way of thinking, in which the artist himself becomes the major element generating both the artistic product and the criteria by which it is to be judged, I shall call the expressive theory of art" [2].

\subsubsection{Practice of Expression Approach by Abrams}

It is very important to know how the expressive approach works. Abrams [2] explained how to practice this approach; the first step is doing the characterized which called "possessing a certain magnitude" by substituting character, plot, or exposition, other elements which had earlier constituted the materials only of the form. The focusing is not only in intrinsic elements but more focus to the center of interest is inward. It is interest emotion, thought, will, rather than scenes, event, and action.

Then the second step is discovering the tendency of the point of view that using the author in works whether the third or first person. It is representative of to the poet in his proper person, and to express experiences and states of mind which can be verified from testimony of the poet's private letters and journal. The last step is the process to know the biography of the author. This process called "the sensation and opinions by the author" so the reader or the researcher can know the author/poet living. All the steps are a critical perspective using to find out the relation of the many elements in the work to the author's state of mind, opinion, and author's ways to solve problems. It is clarified in the following quote: 
"Will be found by the attentive reader to have such connection with the main work as may give them claim to be likened to the little sells oratories, and sepulchral recesses, ordinarily included in these edifices" [2].

\subsubsection{Poverty Theory}

Poverty generally is known as a condition of economic inability to follow people's live standard in an area. This condition of incompetence is characterized by the low-income ability to fulfill basic needs like food, clothing and shelter. Poverty affects living a person's standard such as: low education and impacts on poor health.

Furthermore, poverty has broad definitions. It is not only a matter of lack financial in the economic sector but also poverty can definition lack of infrastructure, human capital, natural capital, etc. This is consistent with what was revealed by Sachs [4] that the poor lack the minimums amount of capital necessary to get a foothold, and therefore need a boost up to the first rung. He divides the kind of the extreme poor lack in to six major kinds of capital: Human capital, Business capital, infrastructure, natural capital, public institutional capital, knowledge capital [5].

\subsubsection{The Factors Cause of Poverty}

Knowing the causes of poverty is needed to provide the best solution to this problem. Auerbach [6] divides two factor causing poverty, these are: First, the individual himself or herself, by his or her own action or inaction, does not seek access to or take advantage of the resources and services he or she needs to bolster personal income and move a state of poverty. Second, the government or relevant political institutions (or in the cases of war-torn nations, a lack thereof), fails to provide to impoverished individuals the access or means by which they may gain access to the aforementioned programs, resources and services.

\subsubsection{The Government or Relevant Political Institutions (First World War)}

Politics made several characters in this novel involved World War 1 in Italy. The character's lives who sent to Italy and the Italian native suffered greatly from the war. The war was very scary; the mayor tells the condition and his disappointment about the very miserable war. The war caused their three cars lose that used for caring out their military duty.

Data 1:

$\begin{array}{ll}\text { Major } & \text { : "You haven't seen it up there, have you?" } \\ \text { Lieutenant Henry } & \text { : "No" } \\ \text { Major } & \text { :"It was very bad. We lost three cars" } \\ \text { Lieutenant Henry } & \text { :"I heard about it" } \\ \text { Major } & \text { : "Yes, Rinaldi wrote you" } \\ \text { Lieutenant Henry } & \text { :"Where is Rinaldi?" } \\ \text { Major } & \begin{array}{l}\text { :"He is here at the hospital. He has had a summer and fall of } \\ \text { it" }\end{array} \\ \text { Lieutenant Henry } & \begin{array}{l}\text { : I believe it" } \\ \text { Major }\end{array} \\ & \begin{array}{l}\text { :It has been bad", the major said. "You couldn't believe how } \\ \text { you were" [7] p. 174-175. }\end{array}\end{array}$


The mayor's sigh continued on while giving Henry directions to return to Bainsizza Hill. He deeply regrets this war because it has made life more chaotic and undirected, like quotation below:

\title{
Data 2:
}

Major Signor Maggiore

Lieutenant Henry

Major Signor Maggiore

Lieutenant Henry

Major Signor Maggiore

\author{
: "You will want to see the Bainsizza" \\ : "I'm glad to see it. I am glad to be back with you \\ again, Signor Maggiore" \\ : He smiled "You are very good to say so. I am very \\ tired of this war. If I was way, I do not believe I would \\ come back" \\ : "Is it so bad?" \\ : "Yes. It is so bad and worse. Go get cleaned up and \\ find your friend Rinaldi" [7] p. 175.
}

The impact of war is not only on abnormal living conditions, unstable economic conditions, war also makes people forced to work even when sick. As Henry's condition, a vulnerability serving as an American ambulance driver for Italy, Lieutenant Henry's complaint about the pain in his leg as follow:

Data 3: "I was tired and my right foot hurt. It seemed silly to lie on the bed with one shoe off, so I sat up and unlaced the other shoe and dropped it on the floor, then lay back on the blanket again" [7] p. 176.

War not only makes people suffer and lack of need life, but also the war made some people become poor conscience and poor souls of humanity values. This was stated by Rinaldi as a surgeon when he saw the wound of his best friend Lieutenant Henry:

Data 4: "It's a crime to send you back. They ought to get complete articulation...., You ought to have more treatment on it with the machines", Rinaldi said [7] p.176177.

The War 1 made the health; mentality and life spirit of the characters in the novel begin very weak. Therefore, they are not fight to seek new hope and return to their hometowns, leaving the Italian war site is not their main priority, as complained by Rinaldi, a surgeon officer seen as follows:

Data 5: "This war is killing me", Rinaldi said, "I am very depressed by it". He folded his hands over his knee [7] p. 177.

Data 6: "But now, baby, it's all over. I don't operate now and I feel like hell. This is a terrible war, baby. You believe me when I say it. Now you cheer me up [7] p. 178.

Data 7: "Don't you feel good yourself, baby?" "I feel like hell". "This war is terrible", Rinaldi said. "Come on. We'll both get drunk and be cheerful. Then we'll 
go get the ashes dragged. Then we'll feel fine...You come back serious and with a liver. I tell you this war is a bad thing. Why did we make it anyway?" [7] p. 178.

\subsubsection{Inaction Individual}

One of causing the poverty is the inaction individual. The despair of the characters that make them not excited about life is not entirely from themselves. The main factor of their despair is war. The strong character in this novel even felt very annoyed because of the war. This condition made him depressed. It has an effect on his mental state to not want think anything even thinks how the needs of daily life.

Data 8: "Now I am depressed myself”, I said. "That's why I never think about these things. I never think and yet when I begin to talk, I say the things I have found out in my mind without thinking" [7] p. 190.

Depression because of due heavy thoughts and chaotic conditions experienced by one of the characters make him very tired drank excess wine to get drunk. This is reflected in the following quotations:

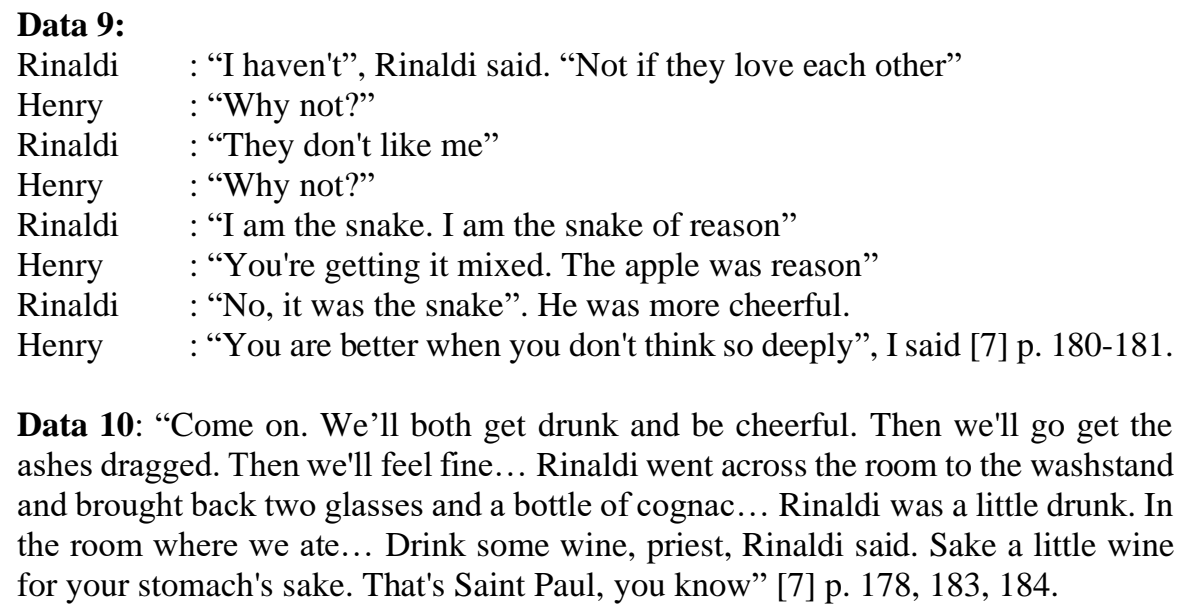

Rinaldi's condition, also experienced by the Major. The stress and depression undermined his body so it looks very thin. Hemingway through Henry as the main character explained very detail:

Data 11: "Hello", he said. "How are you?" He looked older and drier... The major came in, nodded to us and sat down. He seemed very small at table [7] p. 173, 183.

\subsubsection{Lack of Education}

Quality education can reduce poverty in the society. If the poverty that exists in parents cannot be eliminated, then the education of poverty can be overcome through education programs for their children. However, in this novel found several phenomena that are still far 
from the reach of education. It can be seen from their way to survive life which still very primitive, as did the fishermen in fishing, as this quotation, Data 12: I rowed up opposite the fisherman's island where there were boats drawn up and men were mending nets [7] p. 272.

From quotation above, the readers can discuss among the fishermen still using the traditional system in their activities. They still use temporary nets while at that time has been in the modern era. There is no knowledge technology used in ease their activity because one of the main reasons is their lack of knowledge in understanding technological developments.

In addition, language knowledge is very great important. Language mastery can make someone get a job easier, and understanding several languages make someone knows the cultural life of other countries. So, it is easier to learn and be accepted in the social life of other people society. The inhibition the knowledge of a person's language is very influential on the path of his career, as the conversation of the following three characters:

\section{Data 13}

Henry : "How long have you been an officer, Ettore?" I asked

Ettore : "Two years. I'm going to be a captain. How long have you been a lieutenant?"

Henry : "Going on three years""

Ettore : :You can't be a captain because you don't know the Italian language well enough", Ettore said. "You can talk but you can't read and write well enough. Got to have an education to be a captain"

Simmons : “... I can command a company in Italian I could learn it in English easy [7] p. 131.

Education as a determinant of career paths is also still reflected in Ettore, Simmons and character who they called Mac in a conversation, but Ettore realizes that touch it requires higher knowledge as Hemingway [7] p. 131 reflected below:

\section{Data 14:}

Simmons : "You'd be a general", said Simmons

Ettore : "No, I don't know enough to be a general. A generals got to know a hell of a lot. You guys think there aren't anything to war. You aren't got brains enough to be a second-class corporal"

Simmons : "Thank God I don't have to be", Simmons said

Ettore : :Maybe you will if they round up all you slackers. Oh, boy, I'd like to have you two in my platoon. Mac too. I'd make you my orderly, Mac"

Mac : "You're a great boy, Ettore", Mac said. "But I'm afraid you're a militarist".

Ettore : "Till be a colonel before the war's over/", Ettore said

Mac : "If they don't kill you"

Ettore : "They won't kill me". He touched the stars at his collar with his thumb and fore finger. "See me do that? We always touch our stars if anybody mentions getting killed" 


\subsubsection{The solutions of Hemingway in eradicating the poverty reflected in A Farewell to Arms}

\subsubsection{Increasing Non-Farm Productivity}

One way to reduce poverty is to open non-agricultural businesses, especially in rural areas to increase productivity. Opening independent employment can help get work and hire other people, more special if we can hold a social entrepreneur. Through entrepreneurship the expansion of the trade sector can touch all fields or various jobs so it is influenced by economic improvement in a society. We can see the efforts made by the characters in A Farewell to Arms below:

a. Opening a homestay business in a rural area, villa in the mountains and hotels in the urban area

One of the very good businesses is to make a home stay, villa or hotel for those who have many funds. As we understand the Villa can be used as a place to stay for tourists, workers who work in an area and so on. In this novel it is explained at the beginning of the novel that there is a wealthy German and made a Villa business like quotation below:

Data 15: They had the complete marble quality of all looking alike. Sculpture had always seemed a dull business still, bronzes looked like something. But marble busts all looked like a cemetery. There was one fine cemetery though the one at Pisa. Genoa was the place to see the bad marbles. This had been the villa of a very wealthy German and the busts must have cost him plenty. I wondered who had done them and how much he got. I tried to make out whether they were members of the family or what; but they were all uniformly classical [2] p. 29.

The interesting thing about this quote is the social system that this anonymous character does. He adorns the villa with classic statues made and carved as sculptors. The two-business people work together and benefit from one another. A German can benefit from the beautiful villa and the sculptor also earns income from the villa owner for his skills.

Business villa, home stay and hotel are a promising business. Therefore, to attract visitors, everything must be understood before establishing it. These are the location of the villa or home stay, beautiful interior, beautiful view and beautiful garden. Another important thing is that the road to the villa must be good and can be accessed by vehicles. As Henry said when describing the villa that attracted him as a visitor in the San Siro area, Milan with Catharine and his friends when they went to watch horse racing.

Data 16: We four drove out to San Siro in an open carriage. It was a lovely day and we drove out through the park and out along the tramway and out of town where the road was dusty. There were villas with iron fences and big overgrown gardens and ditches with water flowing and green vegetable gardens with dust on the leaves. We could look across the plain and see farmhouses and the rich green farms with their irrigation ditches and the mountains to the north [7] p. 136.

Data 17: There were some lovely villas. Once, before the war, going up to Cortina D'Ampezzo I had gone along it for several hours in the hills. Up there it looked like a trout stream, flowing swiftly with shallow stretches and pools under the shadow of the rocks [7] p. 270. 
Data 18: There was an inn in the trees at the Bains de l'Alliazwhere the woodcutters stopped to drink, and we sat inside warmed by the stove and drank hot red wine with spices and lemon in it [7] p. 322.

In addition to the interior and exterior of the homestay or villa that pleases visitors are the service and attitude of the owner and employees must also be considered. These can make customers feel free and feel valued. Moral and human nature in making a business cannot be underestimated. If the visitor feels impressed with the attitude friendly owner, the visitors will be loyal to use the place if they visit again. They can also recommend their friends to choose the place.

Data 19: In the spring when it is nice you could come and enjoy it. We could put the little one and the nurse in the big room that is closed now and you and Madame could have your same room looking out over the lake. "I'll write about coming", I said. We packed and left on the train that went down after lunch. Mr. and Mrs. Gottingen came down to the station with us and he hauled our baggage down on a sled through the slush. They stood beside the station in the rain waving good-by. "They were very sweet", Catherine said. "They were fine to us [7] p. 327.

Previously Henry and Catharine were impressed because they were welcomed and friendly by the owner of the homestay. The fact in this novel also reflects how the quality of products such as beds, rugs, and bedrooms can make customers feel welcome.

Data 20: We came into Lausanne and went into a medium-sized hotel to stay. It was still raining as we drove through the streets and into the carriage entrance of the hotel. The concierge with brass keys on his lapels, the elevator, the carpets on the floors, and the white washbowls with shining fixtures, the brass bed and the big comfortable bedroom all seemed very great luxury after the Guttingens. The windows of the room looked out on a wet garden with a wall topped by an iron fence. Across the street, which sloped steeply, was another hotel with a similar wall and garden. I looked out at the rain falling in the fountain of the garden [7] p. 328.

b. Become a sculpture carver

Henry as the main character pays attention to the beautiful office where her girlfriend worked. The officer decorated with marble statues. The statues are painted so neat and beautiful. It was originally a statue that was bought by a wealthy German villa owner:

Data 21: ... bronzes looked like something. This had been the villa of a very wealthy German and the busts must have cost him plenty. I wondered who had done them and how much he got [7] p. 29.

c. A doctor can use his skills to open a clinic

Health cannot be separated from basic human needs. The doctors who have obtained academic recognition can use his ability to open a business. This business can provide additional income for a doctor. In addition, the business also gives employ pharmacists, general practitioners or specialist doctors so that unemployment rates are reduced and health access for 
the community is easier. This is reflected in the conversation of Miss Gage's nurse with lieutenant Henry while being treated in an Italian hospital, in the novel as follows:

Data 22: "What does he do there? Swim?"

"No. He has a clinic there"

"Why don't they get another doctor?"

"Hush. Hush. Be a good boy and he'll come" [7] p. 94.

\subsubsection{Improved Agricultural Productivity}

One way to control the conditions of poverty in meeting basic daily needs especially in war condition is farming. Planting does not require as much funding as other businesses.

Agricultural conditions at Udine in northeastern Italy reflected in the novel are very concerning. As a former war zone, the condition of the fields becomes poorly maintained and the plants dry. Field workers turned to tamping stone. This is reflected in the novel below:

Data 24: It was getting dark. Guns were firing from the field behind the village and the shells, going away, had a comfortable sound [7] p. 198.

However, there is a new ex-war agriculture in this novel attracts them to be able to rise from their slumps. They tilled the fields with irrigation ditches. Comprehensive care for their fields produces green plants. In addition, farmers are also very smart because they choose to farm in strategic areas; horse visiting areas and it easily accessible by transportation to bring their agricultural products.

Data 25: We could look across the plain and see farm houses and the rich green farms with their irrigation ditches and the mountains to the north. There were many carriages going into the race track and the men at the gate let us in without cards because we were in uniform. We left the carriage, bought programmers, and walked across the infield and then across the smooth thick turf of the course to the paddock. The grandstands were old and made of wood and the betting booths were under the stands and in a row out near the stables [7] p. 137.

\subsubsection{Education}

Education can make people more productive. Through education people get the skilled so that they create new ideas and innovations for the continuation of the nation's life. It cannot be denied that the role of education in eradicating poverty is quite significant.

Military education creates militants who have the mental and physical strength to serve the state. After passing the education process the militants will get a degree. This level of education can pursue a high career level in accordance with military rank.

Data 26:

Ettore : "You got to have an education to be a captain. Why don't you go in the American army?"

Simmons : "Maybe I will. I wish to God I could"

Ettore : "Oh, boy, how much does a captain get, Mac?" 
Simmons : "I don't know exactly. Around two hundred and fifty dollars, I think" [7] p. 131.

The following quotation is the reward to the army. They can meet basic need and their other needs because of her education:

Data 27: "Jesus Christ what I could do with two hundred and fifty dollars. You better get in the American army quick, Fred. See if you can't get me in". "All right". "I can command" [7] p. 131.

Another education reflected in the novel is teacher education. Through education can educate the nation and as an appreciation of it can be used as a profession.

Data 28: He had a sister, who had been sent to America with him at the same time to live with the uncle, who would graduate from normal school this year. He was a legitimate hero who bored every one he met [7] p. 133.

\subsubsection{Give Each Other As Obligation to the Poor People}

Humans as social beings must help each other. There is right of the people on our self, one of that is giving what the poor needed who live around us. This is exemplified by the main character when his foot hard illness, he gives money to people who have helped him bring his things.

Data 29: I did not speak to her. "There is money in my pocket", I said to the porter. "In the buttoned-down pocket". The porter took out the money. The two stretcherbearers stood beside the bed holding their caps. "Give them five lire apiece and five lire for yourself. My papers are in the other pocket you may give them to the nurse". The stretcher-bearers saluted and said thank you [7] p. 89.

Another act that the people can do to help other is giving loans to the needy as the supporting characters do in the novel.

Data 30: One evening I was short of money and George loaned me a hundred lire. "That's all right, Tenente", he said. "I know how it is. I know how a man gets short. If you or the lady need money, I've always got money” [7] p. 120.

\subsection{Discussions}

In this part the researchers explained what were analyzed in the findings contain the factors cause poverty and the solution through A Farewell to Arms novel. 


\subsubsection{The Factors Cause Poverty Reflected in Hemingway's Novel $A$ Farewell to Arms}

\section{a. The Government or Relevant Political Institutions (First World War) Reflected in Hemingway's A Farewell to Arms}

As revealed in data 1 and data 2 , one of the main causes of the economic instability of the characters in meeting their basic needs is the political situation of the government that is facing a World War 1. The compulsion to find the basic needs of the characters around the location of the war led them to commit criminal acts shown in data 1. In addition, this war condition also makes them suffer so badly that they cannot carry out activities to fulfill their needs in data 3 and data 4 . These conditions make them unable to move to find a safe location far from war as data 2 . The worst thing due to war is the mental condition of the characters who has been very weaken so that it condition makes them desperate to survive on data 5 , data 6 and data 7 .

\section{b. Inaction Individual Reflected in Hemingway's A Farewell to Arms}

As stated in data 8 that the main character never thinks again about what is happening around him. When the characters in novel try to find the ways out of a big problem such as their security problems or how they support the necessities of life, they suddenly choose to give up thinking. The great depression made them in extreme poor position.

\section{c. Lack of Education Reflected in Hemingway's A Farewell to Arms}

Through A Farewell to Arms novel on data 12 and data 13 Hemingway has shown us that one of the factors made the people difficult get a highest position in their career is a lack of education. In data 13 it is explained that the obstacle for lieutenant to obtain the captain position is his minimum language knowledge, lack of ability to read and to write. These three basic abilities were conveyed by Hemingway through his novel to educate readers to focus more on mastering language knowledge as general knowledge that should be possessed.

\subsubsection{The Solutions of Hemingway in Eradicating the Poverty Reflected $A$ Farewell to Arms}

\section{a. Increasing Non-Farm Productivity Reflected in Hemingway's A Farewell to Arms}

Non-agricultural business is a strategic way in eradicating poverty. Opening a business is the right choice even though the challenges are greater than be workers in an institution. However, an independent entrepreneur can get a lot of profit. Not only that, a ruler can directly employ other people so that the poverty number in society can be reduced.

Hemingway through the plot exposition of this novel has described how the success of a non-agricultural businessman and how they can get a decent life. In this novel there are four kinds of three businesses that can be used as references in shaping business. These efforts are divided into two types of objects namely; Business references for those who have small capital and live in rural or mountainous areas and Hemingway also provides alternative business examples for those who have large capital in urban areas. The independent businesses are as follows: 


\section{1) Opening a Home-stay Business in a Rural Area, Villa in the Mountains and Hotels in the Urban Area}

The increasing tourism industry makes home-stay, villa or hotel businesses be a very appropriate alternative. Area tourism in the countryside or mountains make tourists or other visitors who while carrying out the job will rent an inn during a tour or while carrying out the job.

Through the exposition plot at the beginning of the novel A Farewell to Arms Hemingway has explained how the success of a German villa entrepreneur can be seen in data 15 . The novel told to readers hat the entrepreneur has a life with very luxurious facilities from his a very large villa as his investment.

Through Henry as the main character in the novel A Farewell to Arms, Hemingway explained to the reader that in homestay entrepreneurship, villas or hotels, visitor's satisfaction is a matter that must be highly considered. The things that can attract the attention of visitors have been reflected by Henry and Catharine when visiting a villa. Data 16 told us that Santiago and Catharine visited a city to walk and they rented a villa. The villa was very interesting because it was built with an iron fence in a very green area with manicured lawns, there is also flowing water, vegetables around it and the green farm with farm houses that makes Catharine and Henry felt very fresh.

In addition of the wonderful views on data 16 , there are also additional references for readers if want to make a villa with a beautiful view. In data 17 Hemingway through the character Henry told that once before the War in the area of Cortina D'Ampezzo in Italy, Henry passed a very luxurious villa which made him very impressed. In front of the villa in a high area there is a trout flowing with water that is filled with rocks. Data 18 also explains that Villa who received Henry's attention when visiting different villas in different plots was also an inn in the trees at the Bains de l'Alliaz.

Data 19 has shown to us that in the end plot Henry and Catharine have lived a long time in a homestay. They were very impressed of the good attitude and the friendly of the homestay owner. It was told when Catharine would birth and they had to go to town. The homestay owners had told them that after the birth process his homestay open to them and he was prepared special a room for their baby. Data 20 taught the reader that the other most important thing when making a homestay or hotel business is the comfort and completeness of the hotel facilities. From the data above Hemingway through the characters taught the reader that there are three things in general that are the center of attention for attracting visitors in running a homestay, hotel or villa business. These are: The attitude of the owners and the employees, interior and exterior of the inn. For more detail, the researcher concludes as follows:

- Hemingway teaches us that the way to attract visitors is to pay attention to the interior and interior beauty of the homestay or villa.

- The villa must be erected in the right location. In this novel the location is described in great detail as well; right at the horse race venue which is visited by many people from inside and outside the city,

- The views around the villa must be beautiful to attract the visitor's attention. The owner of the villa should choose a quiet place and arrange the villa with a wide and cool view as depicted in the novel that the location of the villa make impresses the main character. It is adjacent to the green areas of agriculture, in the north side there are mountains which are no less beautiful, and also in another quote explained that the river area also makes the visitors feel comfortable.

- The homestay or villa must be clean with servants who maintain a friendly attitude. 
- The items used in the visitor's room must be in good quality or minimal in a condition suitable for use. So that the visitors feel comfortable and satisfied.

\section{2) Become a Sculpture Carver}

Data 21 shown Henry was amazed at the sculpture work on display at the German Villa. Sculpture is a three-dimensional work of art that is very interesting because of its beauty. The sculpture is adapted to various characters according to consumer demand. In the novel Hemingway teaches us that there is a character become sculptor who succeeds in making sculptures. He sells his work to villa owners to enhance the look of the villa. The results obtained can be used to meet his basic needs in daily life. As is almost everyone understanding that the art work specially uses handmade way has a fantastic selling value.

\section{3) A Doctor Can Use His Skills to Open a Clinic}

Health is the most important part in human life. Therefore, health fulfillment is a matter that must be considered. Seeing this, an expert doctor can create a clinic. The clinic that was created as an application of doctor's education for helping human beings, and it could also be used as income to meet the doctor's daily needs. Opening a clinic is not only beneficial for its owner but it can also employ other people such as pharmacists to show medicine to consumers. The expert doctor who has a clinic can increase his income and also reduce the amount of unemployment in a society.

Hemingway was explained how important an expert doctor to his patients through Henry as the main character in A Farewell to Arms novel. Henry asked Miss Gage, the nurse, for the doctor position when he was not seen at the hospital. The nurse said that the doctor also worked in his clinic besides being a doctor in government hospital. His clinic is always visited by patients and of course this gives benefits to doctors and workers in that place and the also give benefits to patients as clinic visitors.

\section{b. Improved Agricultural Productivity Reflected in Hemingway's A Farewell to Arms}

Data 25 has shown to the readers that farming is not a waste of work. Farming is a job that doesn't spend a lot of money and it is very suitable in rural areas. The results of agricultural production can be consumed for meet daily needs and it also can be sold mainly to urban areas.

Hemingway through the portrayal of the main character, Henry, explained that there was a rice field drawn in the novel with the utmost care. The process carried out by farmers in the novel can see below:

- Farmers make the perfect irrigation process in their rice fields in the mountainous area. The irrigation process carried out by farmers to make the flow of water very regular on the plants. Therefore, the results of agriculture are growing very fertile in the mountains.

- The farmers in novel are very smart and know very deeply the strategies. They choose to farm in strategic areas; horse visiting area with many visitors, it easily accessible by transportation to bring their agricultural products to urban areas and the visitor in horse racing show can buy the farmer's agricultural products.

\section{c. Education Reflected in Hemingway's A Farewell to Arms}

The education is a medium where people gain knowledge to develop ideas and make new innovations within the scope of work. The quality education is fundamental in advancing and prospering the life of a nation. Skills acquired from the field of education create creative human resources and it make them have a highly competitive spirit. 
As revealed in data 26 and data 27, Hemingway wrote two conversations between two military members Ettore and Simons. Through this conversation it is explained that the quality of one's education in the world of work can increase his rank so that his acquisition can also increase. Education can give someone a good position. Through education, someone can be guaranteed because they already have different skills from people who never go to school. The main qualification for accepting someone as a member of the military are those who have been through military education, and it is very possible to get a promotion if their quality of education continues to be improved.

In additional data 28 , there is character who be a new graduate. She will become a teacher. Being a teacher is a noble job. In addition to getting guaranteed income every month, this work also maintains and develops the quality of human resources for the life of a nation that is sustainable.

\section{d. Give Each Other As Obligation to the Poor People Reflected in Hemingway's $A$ Farewell to Arms}

Data 29 and data 30 teach us that siding with the poor is a very noble attitude. This action can help them to fulfill their basic daily needs. No matter how rich a person, he cannot live alone and he will always need someone else's presence. Therefore, as social beings, helping each other has become an obligation in society.

\section{Conclusion}

The research results show that there are three main factors reflected in A Farewell to Arms novel that made poverty rampant in Italy since world war I. The first as a main cause is the government or relevant political institutions that caused the World War 1 . The second was found that other factors were made poverty is the condition of the character's depression made them anxiety, so they did not have the power to continue their lives more and even met their basic daily needs. The last factor is lack of education.

The solutions reflected in A Farewell to Arms novel are divided into three kinds. The First is increasing non-farm productivity, consisting of; opening an independent business, in this novel described there are characters who open a home stay business in rural areas, villas and hotels business for character have much capital in urban areas. Then the researchers found the character narrated by Henry as main character that there is one became a sculptor, and there was also other character who worked as doctor open clinics. The independent businesses not only benefit to the owner but also to the people around him. The second is through improving education. Education give and improving skill someone that will affect in various fields. The last is giving or helping each other in meeting basic needs, so the absolute poverty can be reducing.

\section{Acknowledgement}

I gratefully acknowledge that the research was sponsored BPI LPDP from the Ministry of Finance of Indonesia. Thank you very much LPDP. 


\section{References}

[1] Horace, "Satires: Epistles and Ars Poetica," H. R. Fairclough, Ed. Harvard: Loeb Classically Library, 1926.

[2] M. H. Abrams, The mirror and the lamp: Romantic theory and the critical tradition, vol. 360. New York: Oxford University Press, 1971.

[3] D. A. F. M. Russell, D. A. Russell, and M. Winterbottom, Ancient literary criticism: the principal texts in new translations. Oxford: Clarendon Press, 1972.

[4] J. D. Sachs, The end of poverty: Economic possibilities for our time. Penguin, 2006.

[5] J. C. Scott, Seeing like a state. Yale University Press, 2008.

[6] J. Currie, A. Auerbach, D. Card, and J. Quigley, "Poverty, the Distribution of income, and Public Policy," New York Russel Sage, 2006.

[7] E. Hemingway, A Farewell to Arms. Scribner, 1929. 